\title{
松島 純一・寺山吉彦（北大耳鼻科）
}

然然飞伝音難㯖が生 $\mathrm{l}$ 、しかも鼓膜に穿孔がない場合は頭部外傷なとの強力な外力が耳 小骨連鎖を障害した時に生ずるが、外耳道に指を入れた程度のごく日常的動作により発作 した報告は見当らない。類似のものとしてAzem らはくしゃみをして实然伝音難聴とめま い、耳鳴が始まり、手術によりアブミ骨底板に多数のき裂が羿められた症例を sudden conductive hearing loss として報告している。われわれは外耳道を指で王迫して突然 伝音難聴を来した症例を経験し、かかる症例の存在は外耳道に加王減圧を行う Impedance audiometryの施行上でも注意するべきであると思い報告する。

\section{症例： 33 才、女性、事務員}

L.eft

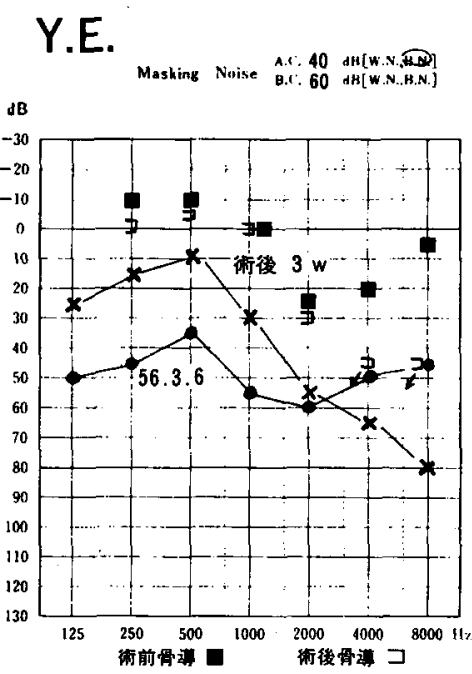

図 1 術前と術後 ( 3 週間後)聴力
主訴：左難聴

現病釈：昭和 56 年 2 月 11 日夜、テレビを 見ながら指で左耳をはじっていた所、突然耳閉 感が出現し、テレビのイヤホンを入れてみたら 聞えないことが判った。耳鳴（ジーン）、めま い（ふらふら感）もあったが装日は消失し、耳 鳴の及時々出現した。吐き気む時々あるといら。 また、強大音により突然蓋があいた感じで聞え がよくなることがあるといら。耳痛、耳漏はない。

既往歴：17才時左急性中耳炎

家族歷：特記すべきことない。

現症: 鼻、後鼻腔、咽、㬋頭、右鼓膜正常、 左鼓膜の緊張部下部に瘏痕閉鎖した穿孔の跡がある。

聴力検查: 右聴力はほほ正常。左耳は図 1 の 如く、気導聴力は $35 \sim 60 \mathrm{~dB}$ 、骨導聴力は $2 \mathrm{KHz}, 4$ $\mathrm{KHz}$ が $25 、 20 \mathrm{~dB}$ で、その他の周波数は-10〜 $5 \mathrm{~dB}$ と 軽度の感音難聴を伴う伝音難聴を示す。スピー

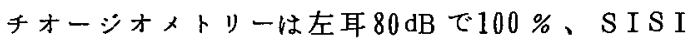

-testは1 KH、0\%、4 KHz 15\%でリクルートメント陰性を示す。チンパノメトリーはAdタイプ、 フブミ骨筋反射陽性で施行中ふらふら感を訴えた。

平衡機能検查：カロリックテストで右は正常、左は反応減弱、右に向ら頭位眼振を認める。

経過：入院の上 3 月 19 日試験的鼓室精查を行った所、図 2 ・3の如くキヌタ骨長脚は細 く、且つその中央部にくびれがあり、被覆粘膜を剝離すると長脚はこの部で仮関節様に離断して いた。両断端は丸く、狭い間陌を介して相対している。病歴で強大音により聞えるようになる ことがあったのは両断端が接したためと思われた。キヌタ骨長脚下半部とフブミ骨とは正常

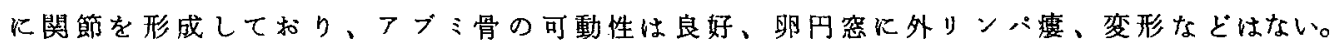
鼓室粘膜は薄く、炎症所見はない。以上に対して耳介軟骨を長方形に採取し、一端に溝を 作りキヌタ骨長脚下端にはめ、他端を鼓膜に接するようにし、鼓索神経に支持させて手術 


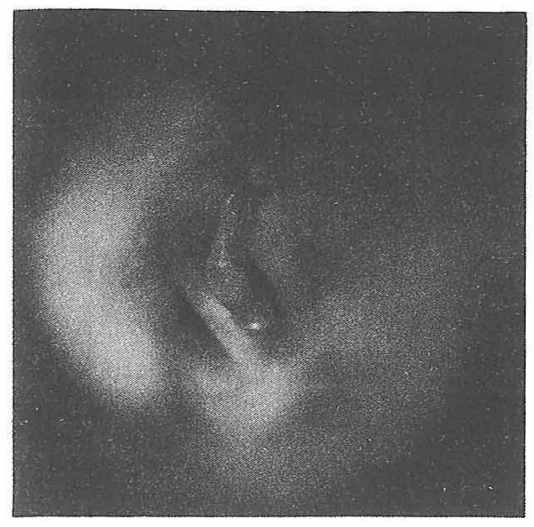

図2

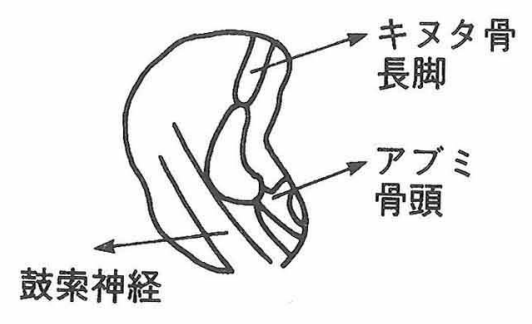

図3

を終っだ。

術後聴力は図 1 の如く気導聴力は $125 \mathrm{~Hz}-1 \mathrm{KHz}$ で 10 $\sim 30 \mathrm{~dB}$ に改善したが $2 \sim 8 \mathrm{KHz}$ は $55 \sim 80 \mathrm{~dB}$ に悪化し骨 導㯖力も2 $8 \mathrm{KHz}$ は $30 \sim 40 \mathrm{~dB}$ 悪化した。又時々ふらら ら感が出現するとのことなので現在経過観察中である。 考按：本症例飞突然生じた難聴の発生機転は 手術所見から見ると、外耳道に指を挿入したた めに内压が上昇し、仮関節様飞接触を保ってい たキ又夕骨長脚の上下の 2 部分が解離したため と考党られる。

長脚にかかるくびれが生じたのは先天性奇形 によるものよりる、長脚全体が細くなっていた ことと緊張部に痕痕があることから過去の中耳 炎による骨萎縮が原因と思われる。

本症例の特徵の 1 つは鼓膜火何ら強圧を加兄 ないような日常的動作火より高度の伝音難聴を 来したことである。最近 impedance audiometry の普及により鼓膜に強い圧が加えられる機会が 增加し、施行中高度の感音難聴になった例の報 告もある。この症例の如く耳小骨連鎖飞脆弱部 位がある時は突然云音難聴が生ずる可能性があ ることを物語っている。

第 2 亿本症例拈よび前記 $\mathrm{A} z \mathrm{em}^{(1)} ら$ の報告例 も 軽度ながら骨導聴力の悪化と前庭症状を伴った ことが注目される。暁ら(2)は外傷の既往のある 瘦孔症状陽性の正常鼓膜例を手術し、脱臼した キヌタ骨長脚がフブミ骨頭上に接していたので これがアプミ骨を压迫したためと考克た。われ われの症例もアブミ骨炕連なるキヌタ骨長脚の下半分がテコ作用によりアブミ骨に陰陽の 加圧を加克内耳炕も影響を及ぽしたものと推定される。

結語：33才の女性で、外耳道を指でほじっている時、突然公音難㯖を生じた症例飞手術

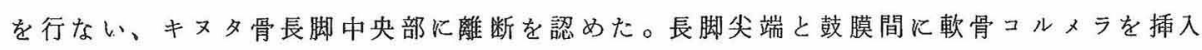
して聴力はかなり改善した。 